\title{
The Two Faces of Personhood: Hobbes, Corporate Agency, and the Personality of the State
}

\begin{abstract}
There is an important but underappreciated ambiguity in Hobbes' concept of personhood. In one sense, persons are representatives or actors. In the other sense, persons are representees or characters. An estate agent is a person in the first sense; her client is a person in the second. This ambiguity is crucial for understanding Hobbes' claim that the state is a person. Most scholars follow the first sense of 'person', which suggests that the state is a kind of actor-in modern terms, a 'corporate agent'. I argue that Hobbes' state is a person only in the second sense: a character rather than an actor. If there are any primitive corporate agents in Hobbes' political thought, they are assemblies, not states. Contemporary political theorists and philosophers tend to miss what is unique and valuable about Hobbes' idea of state personality because they project the idea of corporate agency onto it.
\end{abstract}

One of the central claims that Thomas Hobbes makes in each of his major political works is that the state is a person. However, he is not clear what kind of person it is. Hobbes scholars have tried to fill in the blank. While Quentin Skinner (1999) argues that Hobbes' state is a 'purely artificial person', David Runciman (2000b) counters that it is a 'person by fiction'. Runciman has apparently won this debate, since most scholars, including Skinner (2005: 178; 2009: 346-47), now agree that Hobbes' state is a person by fiction (e.g., Abizadeh, forthcoming; Brito Vieira, 2009: 150-60; Turner, 2016: 213-14). The issue appears to be settled.

Yet there remains a deeper ambiguity in Hobbes' claim that the state is a person, which follows from the fact that he defines and uses 'person' in two opposite ways. In one sense, 'a Person, is the same that an Actor is' (2012: XVI. 244). In the other sense, 'a Person, ... is he that is Represented' by an actor (Ibid. XLII. 776). An estate agent is a person in the first sense; her client is a person in the second. Is the state a representative person or a represented person—an actor who plays a role, or a character whose role is played? I argue 
that Hobbes' state is not a fictional actor, as it is commonly understood, but a fictional character of a very specific kind.

The debate about Hobbes' idea of state personality is of much more than historical interest. Hobbes' theory of the state has a prominent place in philosophical debates about the nature of collective action, where it is often described as a rudimentary account of corporate agency (e.g., Erskine, 2001: 75; List and Pettit, 2011: 7, 76). I argue that these interpretations of Hobbes depend on a mistaken equation of 'person' with 'agent'. Contemporary philosophers and political theorists tend to miss what is unique and valuable about Hobbes' theory of the state because they project the idea of corporate agency onto it.

The article has five sections. The first describes the tension in Leviathan between Hobbes' definition of 'person' and his claim that the state is a person. On one hand, he says that persons are actors or representatives. One the other, he says that the state is a person but not an actor or representative. The second section resolves this tension using Hobbes' alternative definition of 'person' from Chapter 42 of Leviathan, which instead defines persons as representees. I show that this sense of personhood is essential for understanding how Hobbes uses 'person' throughout his political works. The third section revisits Hobbes' theory of the state in light of the Chapter 42 definition. I argue that Hobbes' state is best understood as a character rather than an actor. Whereas a Hobbesian assembly is a fictional actor, Hobbes' state is a fictional character. The fourth section challenges contemporary interpretations of Hobbes' theory of the state. I show that it is not a rudimentary theory of corporate agency, as it is often described, but a forgotten alternative to thinking of the state as a corporate agent. The fifth section shows that, if the State." Forthcoming in the European Journal of Political Theory. 
there are any rudimentary corporate agents in Hobbes' political thought, they are assemblies. What makes Hobbes' idea of personhood unique and valuable is that it decouples personhood from metaphysical conceptions of agency; it explains how states and other entities can be persons even though they do not have any intrinsic capacity for intentionality or action.

\section{The Skinner-Runciman Debate}

Hobbes defines the state or 'Common-wealth' as a 'Multitude [of men] united in one Person' (Hobbes, 2012: XVII. 260). ${ }^{1}$ Although he had developed an elaborate typology of persons in the previous chapter, he does not tell the reader what type of person the state is. Nowhere does he provide an explicit answer. His many descriptions of the state invite confusion: 'by Art is created that great LEVIATHAN called a COMMONWEALTH, or STATE, (in latine CIVITAS) which is but an Artificiall Man' and, as he later calls it, a 'Mortall God' (Hobbes, 2012: Intro. 16, XVII. 260).

Skinner (1999) and Runciman (2000b) have tried to figure out where in Hobbes' typology of persons the state fits. The focal point of their debate is the definition of 'person' at the beginning of Chapter 16 of Leviathan.

A PERSON, is he, whose words or actions are considered, either as his own, or as representing the words or actions of an other man, or of any other thing to whom they are attributed, whether Truly or by Fiction.

When they are considered as his owne, then is he called a Naturall Person: And when they are considered as representing the words and actions of an other, then is he a Feigned or Artificiall person. (Hobbes, 2012: XVI. 244)

\footnotetext{
${ }^{1}$ Hobbes provides similar definitions of the state in his earlier works (Hobbes, 1994: XX.1, XIX.8; Hobbes, 1998: V.9, X.5). I cite The Elements of Law and De Cive according to the chapter and paragraph numbers, which are the same for every edition.
} 
Hobbes uses an analogy with representation in the theatre to illustrate this rather convoluted definition. He points to the common etymology of 'person' and the Latin 'persona', which 'signifies the disguise, or outward appearance of a man, counterfeited on the Stage' and 'more particularly that part of it, which disguiseth the face, as a Mask' (Ibid.). The person is not the mask itself, but the actor who wears it: 'a Person, is the same that an Actor is, both on the stage and in common Conversation'-namely, a 'Representer of speech and action' (Ibid.). To 'personate' someone or to 'beare his person' is to speak or act in his name.

Skinner and Runciman agree on many points of interpretation: (1) persons are actors or representatives; (2) natural persons are those that act in their own names, such as defendants who represent themselves in court; (3) artificial persons are those that do not act in their own names (but a subtle disagreement remains, as I discuss below). Their main point of contention is whether the state is represented 'truly' or 'by fiction'. Skinner (1999: 21-22) argues that Hobbes' state is best described as a 'purely artificial person'. Like a character in a play, the state is purely artificial because it is incapable of being a natural person, or of acting in its own name. The state acts only through its representatives. But unlike a character in a play, the state is represented truly because it is truly considered to be responsible for its representatives' actions. Actions performed in the name of the state generate real responsibilities, such as debts and contractual obligations; actions performed in the name of Harry Potter do not. Runciman (2000b: 271-73) counters that Hobbes' state is a 'person by fiction'. Although we attribute actions to the state, we do so only by fiction, since the state cannot truly 'own up' to these actions any more than Harry Potter can. The burdens of the state's debts and contractual obligations must be borne by human beings. 
Following Skinner's (2005: 178; 2009: 346-47) concession on this point, I take it to be settled that the state is represented by fiction. ${ }^{2}$ I focus instead on Skinner and Runciman's side-debate about the meaning of 'artificial person', which points to a more fundamental issue about what kind of person Hobbes' state is.

Skinner (1999: 11-12) argues that an artificial person is someone who is represented by someone else, such as a defendant who is represented by a lawyer. He points to the grammar of the following sentence: 'when [the words and actions of a person] are considered as representing the words and actions of an other, then is he a Feigned or Artificiall person' (Hobbes, 2012: XVI. 244). While the structure of the paragraph suggests that the referent of 'he' in the second clause is 'a person', which implies that an artificial person is a representative, Skinner argues that the referent of 'he' should be 'an other', which implies that an artificial person is instead a representee. According to the common reading of this passage, a lawyer is an artificial person when she represents a client. According to Skinner's reading, her client is the artificial person.

Skinner acknowledges that his interpretation does not fit well with the remainder of Chapter 16. As Hobbes (2012: XVI. 244) later writes, 'Of Persons Artificiall, some have their words and actions Owned by those whom they represent'. The artificial persons that Hobbes refers to here are clearly representatives. Moreover, if a person is 'a Representer, or Representative' (Ibid.), then an artificial person should be an artificial representative. To justify his unconventional reading, Skinner (1999: 12) relies heavily on Chapter 15 of $D e$ Homine, where Hobbes inverts his definition: 'a person is someone to whom the words and

\footnotetext{
${ }^{2}$ However, as Douglass (2014: 141) points out, 'what the [Skinner-Runciman] exchange is lacking is a clear definition of "fiction"'. This is an important problem that I cannot adequately address here.
} 
actions of men are attributed, whether they are his own or those of someone else. If they are his own, then the person is a natural one. If they are those of someone else, then the person is a fictional one' (Skinner's translation). ${ }^{3}$ Whereas Chapter 16 of Leviathan defines an artificial person as someone whose words or actions are attributed to someone else (a representative), Chapter 15 of De Homine defines a fictional person-which Skinner in this case takes to be the same as an artificial person-as someone to whom someone else's words or actions are attributed (a representee). The latter, he suggests, is Hobbes' considered definition of 'artificial person'.

Runciman (2000b: 269-72) replies that Skinner has artificial personhood upside down: 'artificial person' ought to be read as 'artificial representative' rather than as 'artificial representee'. The artificial person in a lawyer-client relationship is the lawyer, not the client. Runciman argues that Skinner's reading puts more weight on Hobbes' later works than they can bear. He points out that the crucial distinctions between natural and artificial persons, and between true and fictional representation, are either missing or muddled in De Homine and the Latin Leviathan (Ibid. 274-77). He contends that the accounts of personhood in these works are not careful clarifications of the one in the English Leviathan, as Skinner assumes, but simplified accounts of personhood that serve Hobbes' political aim: to rule out the possibility that the state can act apart from the sovereign. Runciman therefore gives priority to the more detailed account of personhood from Chapter 16 of Leviathan, where Hobbes defines persons as representatives: natural

${ }^{3}$ Skinner (1999: 12) also appeals to the Latin Leviathan. Although he claims that 'the persons whom Hobbes had initially classified as artificial are now contrasted rather than equated with representatives', his own translation of the relevant passage suggests otherwise: 'if [a person] acts in the name of someone else, then the person is Representative of the one [i.e., the person] in whose name he acts' (Ibid.). The representative and the representee are both persons. 
persons represent themselves; artificial persons represent others; artificial persons 'represent truly' when they are authorized by the entities that they represent; and artificial persons 'represent by fiction' when they are authorized by third parties (Ibid. 269-70). Runciman has the vast majority of Hobbes scholars on his side. Most, both before and after Runciman, also follow the definition of 'artificial person' as 'representative' from Chapter 16 of Leviathan (Forsyth, 1981: 197; Gauthier, 1969: 121-22; Hood, 1964: 164; Pitkin, 1967: 15-16; Tukiainen, 1994: 46; cf. Copp, 1980: 582-83; Green, 2015: 27). Pettit (2008: 56) neatly summarizes the standard interpretation of Hobbesian personhood: 'Hobbes's view, to put it in a slogan, is that there are no persons but spokespersons. Natural persons are spokespersons for themselves, acting and speaking in their own name, and artificial persons are spokespersons for another'.

Yet if 'there are no persons but spokespersons', it is difficult to see how the state could be a person of any kind. The state can speak neither for itself nor for anyone else. It requires a representative-a sovereign - precisely because it cannot be a representative. As Hobbes takes great pains to show, the state 'can do nothing but by the Person that Represents it', and the words and actions that we attribute to it are the words and actions 'onely of the Soveraign' (Hobbes, 2012: XXIV. 388). ${ }^{4}$ Skinner (1999: 11, note 65) clearly recognized the problem here: 'If we adopt Hobbes' initial proposal and call representatives artificial persons, then sovereigns are artificial persons while states are not'. This is the thought that led Skinner to question the standard interpretation of Hobbesian personhood: the state is an artificial person (hence 'Artificiall Man'); but the state is a representee, not a

\footnotetext{
${ }^{4}$ See Hobbes (2012: XXI. 332, XXXI. 554) for additional statements that the state acts only through the sovereign. 
representative; so some artificial persons must be representees rather than representatives.

Runciman (2000b: 272-73; 2009) is well aware that Hobbes' state is not really a representative or actor. But unlike Skinner, he does not recognize the tension between Hobbes' definition of 'person' as 'actor' and his claim that the state is a person. The phrase, 'by fiction', fills the gap. The state is not a natural actor like a human being, nor an artificial actor like an assembly, but an actor 'by fiction'. Runciman compares the state to other 'persons by fiction', such as 'bridges and madmen', which are likewise 'incapable of responsible action' (Ibid. 271). For a bridge to be a person, 'both the owners and the representative of the bridge [must] act in such a way as to ensure that it appears that the bridge is itself acting responsibly' (Ibid. 272). Similarly, the actions of sovereigns and subjects together sustain the fiction that states 'truly are persons, truly capable of the actions that personal responsibility requires' (Ibid.).

Emphasizing 'by fiction' does solve the problem. For one thing, Hobbes never uses the phrase, 'person by fiction'; he refers only to things that are 'represented by Fiction' (2012: XVI. 246). 'Persons by fiction' are Runciman's invention, just as 'purely artificial persons' are Skinner's invention. Further, it is not clear from Chapter 16 that things that are represented by fiction are therefore persons, as Runciman assumes. Hobbes (2012: XVI. 246-48) says that 'Inanimate things, as a Church, an Hospital, a Bridge', 'Children, Fooles, and Mad-men', and even 'An Idol, or meer Figment of the brain, may be Personated' (emphasis added). As Martinich (2016: 228) points out, only in De Homine (1658) and the Latin Leviathan (1668) does Hobbes say that 'an inanimate thing can be a person' (1991: 
XV.4; 2012: 246-47). ${ }^{5}$ In Chapter 16 of the English Leviathan, there is only one instance in which Hobbes clearly says that something becomes a person by being represented: 'A Multitude of men, are made One Person, when they are by one man, or one Person, Represented' (2012: XVI. 248). But the definition of 'person' as 'representative', which Runciman follows, is not sufficient to decipher this crucial passage: Hobbes does not mean that a multitude becomes a representative when it is represented by a representative. As I argue in the following sections, Hobbes uses 'person' in two opposite ways, and it is necessary to recognize this in order to fully understand what kind of person the represented multitude is.

In sum, while Runciman provides decisive reasons to reject Skinner's interpretation of Hobbesian personhood, his own interpretation is also untenable. On one hand, he maintains that all persons are representatives. On the other, he maintains that states (and other incapable entities), which are not representatives, are nevertheless persons. This inconsistency is a problem not only for Runciman, but for anyone who exclusively follows Hobbes' definition of 'person' from Chapter 16 of Leviathan. If we take persons to be representatives, as most Hobbes scholars do, then Hobbes' state is no person at all. As I show in the next section, the source of the problem is that many Hobbes scholars have focused too narrowly on the definition of 'person' from Chapter 16 of Leviathan.

\section{The Two Faces of Personhood}

In his discussion of the Holy Trinity in Chapter 42 of Leviathan, Hobbes (2012: XLII. 776) provides another definition of 'person': 'a Person, (as I have shewn before, chapt. 13.)

${ }^{5}$ I cite De Homine according to the chapter and paragraph numbers, which are the same for every edition. 
is he that is Represented, as often as hee is Represented'. He then describes God as 'three Persons in the proper signification of Persons; which is, that which is Represented by another' (Ibid.). God is one person as represented by Moses, another person as represented by Christ, and yet another person as represented by the Apostles and their successors. Whereas Chapter 16 says that a person is a representative, Chapter 42 says that a person is a representee.

Hobbes' inversion of his definition of 'person' has not gone unnoticed (Abizadeh, 2012: 131, note 85; Brito Vieira, 2009: 169, note 69; Martinich, 2005: 228; Pettit, 2008: 73). Although the Chapter 42 definition has a prominent place in discussions of Hobbes' theology (Abizadeh, forthcoming; Brito Vieira, 2009: 213-14; Wright, 2006: 198), it is rarely mentioned in discussions of his political thought, and it is entirely absent from Skinner and Runciman's debate about what kind of person the state is. This neglect of the Chapter 42 definition is especially odd given that Hobbes' theological and political thought are so closely connected (Lessay, 2009; Runciman, 2009: 15, note 1). The principle that underpins his doctrine of the Holy Trinity-'it is consequent to plurality of Representers, that there bee a plurality of Persons' (Hobbes, 2012: XLI. 772)—also underpins his claim that the state must have a single representative. For the same reason that 'God, who has been Represented (that is, Personated) thrice, may properly enough be said to be three persons' (Ibid. XLII. 776), a multitude with three representatives is 'not one Person, nor one Soveraign, but three Persons, and three Soveraigns' (Ibid. XXIX. 512). I argue that the Chapter 42 definition is just as important as the Chapter 16 definition for understanding how Hobbes employs the concept of personhood in his political thought. 
The parenthetical reference to Chapter 13 in the Chapter 42 definition presents a puzzle. The former chapter ('Of the Naturall Condition of Mankind') does not provide a definition of 'person', so the reference must be an error. Hobbes most likely meant to refer to Chapter $16 .{ }^{6}$ However, this makes the reference even more puzzling. He appears to have defined 'person' as 'representee' and directed the reader to the opposite definition all in the same sentence. One possibility is that he contradicted himself in a moment of uncharacteristic carelessness. A more plausible explanation is that the Chapter 16 and Chapter 42 definitions describe two sides of the same concept. Hobbes' concept of personhood is ambivalent: persons can be representatives, representees, or both at the same time.

There are already hints of this ambivalence in Chapter 16 of Leviathan. Hobbes (2012: XVI. 244) claims that 'persona', which denotes 'a Mask or Visard', 'hath been translated to any Representer of speech and action, as well in Tribunalls, as Theaters'. As Brito Vieira (2009: 168-69) points out, 'The inference is troubling because the theatrical mask is not the actor, but he whom the actor represents: more correctly, a representation of the represented (fictional) character'. The abrupt switch from 'persona as mask' to 'person as actor' is indicative of Hobbes' ambivalence about whether persons are representatives or representees.

This ambivalence is borne out in Hobbes' usage of 'person'. His usage in Part II of Leviathan ('Of Commonwealth') corresponds as often to the Chapter 42 definition as it does to the Chapter 16 definition. For example, when Hobbes (2012: XXIII. 376) writes, 'every man, or assembly that hath Soveraignty, representeth two Persons', he does not mean that

${ }^{6}$ Malcolm takes Chapter 16 to be the intended referent. See Hobbes (2012: XLII. 776). 
every sovereign represents two representatives. The sovereign is the representative. The persons in this context are the things that the sovereign represents, or the roles that the sovereign plays—namely, the state and the sovereign. ${ }^{7}$ A monarch, for example, represents the state in public and himself in private. Similarly, when Hobbes (2012: XXIII. 380) writes, 'in their Seats of Justice [judges] represent the person of the Soveraign', his point is that judges represent the sovereign. He does not mean that judges represent the representative of the sovereign. The person is the role that the judges play, not the actor who plays the role. Even in the phrase, 'bear a person', the person is the representee. In Hobbes' favourite example, Cicero is the representative, and the three persons that he bears are the three roles that he plays: the role of himself, the role of his adversary, and the role of the judge (Ibid. XVI. 244). Representatives are the things that bear persons; they are not the persons that are borne. Hobbes' neglected definition of 'person' from Chapter 42 is indispensable for understanding how he uses the word.

However, the Chapter 16 definition is equally indispensable. Hobbes often uses 'person' as a synonym for 'representative', such as when he describes the sovereign as 'the Person of the Common-wealth'. For instance, he says that 'In all Courts of Justice, the Soveraign (which is the Person of the Common-wealth,) is he that Judgeth' (Ibid. XXVI. 422) and that 'they that give Counsell to the Representative person of a Common-wealth, may have, and have often their particular ends, and passions' (Ibid. XXV. 404). He uses 'person' to mean 'representative' even in Chapter 42. Although he defines persons as representees near the beginning of the chapter (Ibid. XLII. 776), he equates 'the Publique Person' with 'the Representant of the Common-wealth' near the end (Ibid. 920). The only way to

\footnotetext{
${ }^{7}$ See Brito Vieira (2009: Chapter 2) and Pettit (2008: 55-58) on the theatrical or role-based character of Hobbes' concept of personhood. 
determine whether any given instance of 'person' in Leviathan refers to a representative or a representee is to use the context as a guide.

Hobbes' usage of 'person' in his early works exhibits the same ambivalence. Although he did not introduce the concept of representation until Leviathan (Malcolm, 2012: 15-17; Skinner, 2007: 168; cf. Douglass, forthcoming), he did use the concept of personhood in The Elements of Law (1640) and De Cive (1642), where he associates personhood with will rather than with representation. Hobbes does not provide italicized definitions of 'person' in these early works, so we have to rely solely on his usage. In some parts of The Elements, Hobbes uses 'person civil' to refer to the state, as in 'a multitude of persons natural are united by covenants into one person civil' (Hobbes 1994, XX.1; see also XIX.8, XXVII.7). In other places, he equates the 'person civil' with the sovereign: 'a person civil [is] either one man, or one council, in the will whereof is included and involved the will of every one in particular; as for example: in this latter sense the lower house of parliament' (Ibid. XXI.11). Both the sovereign and the state-both the giver and the receiver of the will—are persons. The same ambivalence is present in De Cive. On one hand, Hobbes describes the state as 'one person formed from several men' (Hobbes, 1998: X.5; see also V.9, XIII.3). On the other, he describes an aristocratic assembly, or 'council of optimates', as a person: 'without a fixed schedule of the times and places at which the council of optimates may meet, there is no longer a council or a single person, but a disorganized crowd without sovereign power' (Ibid. VII.10). Hobbes' concept of personhood was Janus-faced from the very beginning.

Once we recognize that Hobbesian persons can be representatives or representees, we can begin to make sense of his later accounts of personhood, which have often puzzled 
Hobbes scholars. Hobbes' definition of 'person' as 'representative' in Chapter 16 of Leviathan is apparently the opposite of his definition in Chapter 15 of De Homine: 'a person is he to whom the words and actions of men are attributed, either his own or another's: if his own, the person is natural; if another's, it is artificial [fictitia]' (Hobbes, 1991: XV.1). ${ }^{8}$ Hobbes inverts his theatrical analogy to match. He begins by describing the distinction in Latin between facies and persona: 'facies if they wished to indicate the true man; persona if an artificial one' (Ibid.). He does not mention facies in Leviathan, where he quickly jumps from saying that a persona is a mask to saying that 'a Person, is the same that an Actor is' (Hobbes, 2012: 244). The point of the distinction between facies and persona is that the actor is distinct from the person, or character, that he plays. When an actor wears a mask, the audience considers his words and actions to be the words and actions of the character that the mask depicts: 'the actor playing Agamemnon in a false face ... was, for that time, Agamemnon' (Hobbes, 1991: XV.1). However, after the play is over, the actor is 'understood without his false face, namely being acknowledged as the actor himself rather than the person he had been playing' (Ibid.). It is clear from Hobbes' definition and his usage in De Homine that the person is the character that the actor plays rather than, as Chapter 16 of Leviathan says, the actor who plays the character.

Hobbes scholars have struggled to reconcile the De Homine and Chapter 16 definitions. Simendic (2012: 153-55) argues that 'artificial person' in De Homine ought to be read as 'representative', as in Chapter 16. While Skinner and Runciman take 'he to whom the words and actions of men are attributed' to be the representee, Simendic contends that "words and actions" of the represented are attributed to the representative and not vice

${ }^{8}$ Compare Skinner's (1999: 12) translation, quoted the first section. 
versa' (Ibid. 155). But if we follow Simendic's interpretation of 'attributed', we then need to explain why Hobbes uses 'attributed' in the opposite way in Chapter 16 of Leviathan, where he says that the thing to which words and actions are attributed is the representee (Hobbes, 2012: XVI. 244). Further, if the De Homine and Chapter 16 definitions are equivalent, then why did Hobbes invert his theatrical analogy in De Homine? Martinich (2016: 329-30), seeing no way to make the two definitions compatible, suggests that Hobbes' definition in De Homine 'may have been different simply because it had a different purpose' and concludes that it 'is of little value to his political theory'. This is implausible given that Hobbes explicitly discusses the state in Chapter 15 of De Homine, which is suggestively titled 'De Homine Fictitio'—'Of Fictional Man'. As Hobbes (1991: XV.3) says, 'Not only can a single man bear the person of a single man, but one man can also bear many'. The definition of 'person' in De Homine cannot be rendered congruent with the definition in Chapter 16 of Leviathan, but nor can it easily be disregarded.

What has gone almost entirely unnoticed is that the definition of 'person' in $D e$ Homine matches the one from Chapter 42 of Leviathan. ${ }^{9}$ Hobbes defines a person as 'he to whom the words and actions of men are attributed' in the former and 'he that is represented' in the latter. The two definitions are equivalent: someone who is represented is, by definition, someone to whom words and actions are attributed. There is clear continuity between Leviathan and De Homine-just not between the Chapter 16 definition and De Homine. The De Homine definition, like each of the Leviathan definitions, is best read as a one-sided definition of a double-sided concept.

${ }^{9}$ The lone exception is Abizadeh (2012: 131, note 85; forthcoming). 
The definition of 'person' from Hobbes' Latin translation of Leviathan is explicitly double-sided: 'A PERSON, is he who does things in his own or another's name. If in his own, he is a proper or natural person; if in another's, he is the representative person of the one [i.e., the person] in whose name he acts' (Hobbes 2012: XVI. 244-45). Here, as Runciman (2000b: 277) points out, 'a person is defined both as an actor and as a non-actor to whom actions are attributed'- 'both as he who acts and whatever is acted for' (see also Martinich, 2016: 330-32). This definition, which Runciman says 'introduces confusion', is actually a symptom of the confusion that was there all along. The definition of 'person' from the Latin Leviathan is the only one that captures the ambivalence of Hobbes' usage.

A complete account of Hobbesian personhood must take both senses of 'person' into account. Hobbes' key distinctions apply to both representative and represented persons.

Table 1. Hobbesian Persons, Representative and Represented

\begin{tabular}{|c|c|c|c|}
\hline \multicolumn{2}{|c|}{ Person } & Representative & Represented \\
\hline & Natural & Represents itself & Represented by itself \\
\hline & Artificial & Represents another & Represented by another \\
\hline & True & True representative & Represented truly \\
\cline { 2 - 4 } & Fictional & Fictitious representative & Represented by fiction \\
\hline
\end{tabular}

Natural persons are both representatives and representees, so it does not make a difference which side of personhood we choose. The class of natural persons by the $D e$ Homine definition is coextensive with the class of natural persons by the Chapter 16 of Leviathan definition even though the definitions are opposite in meaning. However, the distinction between representative persons and represented persons becomes crucial when we consider artificial persons. While artificial persons in the first sense represent others, artificial persons in the second sense are represented by others. True artificial persons are those that are simultaneously natural persons: on the representative side, 
lawyers and estate agents; on the represented side, their clients. Fictional artificial persons are those that are not also natural persons: on the representative side, assemblies; on the represented side, corporate and incapable entities. The next section explains how each type of person figures in Hobbes' political thought. .

\section{The (Represented) Person of the State}

A complete understanding of Hobbes' theory of the state requires both senses of personhood, as well as the distinctions between natural and artificial persons and between true and fictional representation. His explanation of how the multitude becomes a person involves several types of persons.

A Multitude of men, are made One Person, when they are by one man, or one Person, Represented; so that it be done with the consent of every one of that Multitude in particular. For it is the Unity of the Representer, not the Unity of the Represented, that makes the Person One. And it is the Representer that beareth the Person, and but one Person: And Unity, cannot otherwise be understood in Multitude. (2012: XVI. 248)

In other words, many persons become one person when they authorize one person to bear their person. This passage means hardly anything until we distinguish the types of persons involved.

The members of the multitude are natural persons. Each individual, acting in his or her own name, authorizes another person to represent the group. The multitude as a group cannot authorize its own representative because it 'naturally is not One, but Many; they cannot be understood for one; but many Authors, of every thing their Representative saith, or doth in their name' (Ibid. XVI. 250). As Hobbes (1998: VI.1a) puts it in De Cive, 'a crowd cannot make a promise or an agreement, acquire or transfer a right, do, have, possess, and so on, except separately or as individuals, so that there are as many promises, agreements, 
rights, and actions, as there are men'. A multitude cannot act as a unit, which is why each natural person must authorize a representative to act in its name.

The person that the members of the multitude authorize is a representative artificial person. If this person is an individual (i.e., a monarch), then he or she is a true representative. If this person is made up of several natural persons (i.e., an assembly), then it is a fictitious representative. An assembly is, as Hobbes (2012: XVII. 352) says, 'artificiall, and fictitious': the artifice of majority rule sustains the fiction that the assembly has a single will. The fictitious character of an assembly explains why it cannot commit a crime or an injustice: 'a body politic [in this context, meaning 'assembly'], as it is a fictitious body, so are the faculties of will thereof fictitious also. But to make a particular man unjust ... there is required a natural and very will' (Hobbes, 1994: XXI.4; see also Hobbes, 1998: VII.14). An assembly can serve as a representative only insofar as its members maintain the fiction that they have a single will, or speak with a single voice. They do this through majority rule, which cancels out contradictory wills or voices.

if the Representative consist of many men, the voyce of the greater number, must be considered as the voyce of them all. For if the lesser number pronounce (for example) in the Affirmative, and the greater in the Negative, there will be Negatives more than enough to destroy the Affirmatives; and thereby the excesse of Negatives, standing uncontradicted, are the only voyce the Representative hath. (Hobbes, 2012: XVI. 250)

However, if the assembly has an even number of members, or if each member has a veto, then the fiction that it has a single voice may break down. The assembly will be 'oftentimes mute, and uncapable of Action' (Ibid.).

The common claim that Hobbes made 'no formal distinction between a democratic sovereign and a monarchical one' (Tuck, 2016: 100) is not entirely true. A monarch is a true representative, or one whose 'civil will' is simultaneously a 'natural will'; a democratic 
or aristocratic sovereign is a fictitious representative, or one whose 'civil will' depends on the fiction that it speaks with a single voice (Hobbes, 1998: VII.14). Hobbes' worry about sovereign assemblies is that this fiction is fragile: 'a Monarch cannot disagree with himselfe, out of envy, or interest; but an Assembly may; and that to such a height, as may produce a Civill Warre' (2012: XIX. 290). Although Hobbes thought democratic and aristocratic assemblies just as sovereign as monarchs, he did draw a conceptual distinction between representative individuals and representative assemblies.

The act of authorizing a single representative person transforms the multitude of natural persons into a represented person by fiction. Whereas an assembly is 'Many men made One [person] by Plurality of Voyces', a state is many men made one person when they are 'by one man, or one Person, Represented' (Ibid. XVI. 248-50). An assembly is a person in the Chapter 16 sense: a 'Representer of speech and action' (Ibid. XVI. 244). The state is a person in the Chapter 42 sense: 'that which is Represented by another' (Ibid. XLII. 776). Hobbes scholars frequently overlook the fact that there are two ways in which a group can be a person (cf. Copp, 1980). An assembly is a person because it is a representative; a state is a person because it has a representative. To use Hobbes' theatrical analogy, an assembly is a fictional actor, while a state is a fictional character. An assembly is like the chorus in an ancient Greek tragedy: it plays a single role, but only by the fiction that it speaks and sings with one voice. A state is like the character that the chorus represents, such as the Elders of Argos in Agamemnon: it is incapable of playing a role, so it must be brought to life by an actor. The state cannot act apart from the sovereign any more than the Elders of Argos can act apart from the chorus. The difference between a state and a character in a play is not that they are different kinds of persons, but rather, as Runciman (2000b: 275-76) puts it, 
that 'one is a person by fiction whose attributed actions are backed up by the actions of real persons, and the other is not'. Whereas subjects take responsibility for the actions that the sovereign performs in the name of the state, no one takes responsibility for the actions that the chorus performs in the name of the Elders of Argos.

While the sovereign represents the state, she (or it) is also represented by her (or its) public ministers. Ambassadors and messengers 'represent the Person of their own Soveraign, to forraign States' (Hobbes, 2012: XXIII. 382), and 'in their Seats of Justice [judges] represent the person of the Soveraign; and their Sentence, is his Sentence' (Ibid. XXIII. 380). The sovereign is therefore both a representative artificial person and a represented artificial person. Public ministers represent the sovereign truly, since they are authorized by the sovereign in whose name they act: 'Publique Ministers ... serve the Person Representative, and can doe nothing against his Command, nor without his Authority' (Ibid. XXIII. 378).

Runciman (2016: 373-74) argues that public ministers represent the state rather than the sovereign. Hobbes does sometimes suggest this reading, such as when he says that public ministers represent 'the Person of the Commonwealth' (2012: XXIII. 376), but he also provides a decisive reason to reject it. Given that 'it is consequent to plurality of Representers, that there bee a plurality of Persons' (Ibid. XLI. 772), ${ }^{10}$ the state would be multiple persons if it had multiple representatives. Further, when Hobbes' provides examples of public ministers, he says that they act 'in the name of the Soveraign', 'represent the person of the Soveraign', 'represent the Person of their own Soveraign', and 'serve the Person Representative' (Ibid. XXIII. 378-82). Although every action that public ministers

${ }^{10}$ Although the 12 Apostles represent the same person of God, this is possible only because the Apostles are a 'councell' (Hobbes, 2012: XLII. 824-28). 
perform is ultimately 'the act of the Common-wealth' (Ibid. XXIII. 382), their actions are attributable to the state only through the sovereign: public ministers represent the sovereign, and the sovereign, in turn, represents the state. Hobbes confirms this reading in his reply to John Bramhall: "All that he objecteth is, that it followeth hereupon, that there be as many Persons of a King, as there be petty Constables in his Kingdom. And so there are, or else he cannot be obeyed" (2011: 393). If a king has as many persons as he has ministers, then public ministers must represent the king rather than the state. Hobbes had a good reason not to allow public ministers to represent the state directly: they may claim to represent the state independently of the sovereign, just as Parliament did around the time of the English Civil War. Portraying public ministers as deputies of the sovereign makes it clear that they are subordinate to the sovereign.

In sum, Hobbes' formula for making a person out of a multitude involves five types of persons. When the multitude of (1) natural persons authorize a representative artificial person, whether (2) an individual (who is a true representative) or (3) an assembly (which is a fictitious representative), they are transformed into (4) a represented artificial person (by fiction). The representative artificial person is simultaneously (5) a represented person (truly) when she (or it) authorizes public ministers to act on her (or its) behalf. Figure 1 describes how all of these persons hang together. 


\section{Figure 1. Hobbes' Theory of the State ${ }^{11}$}

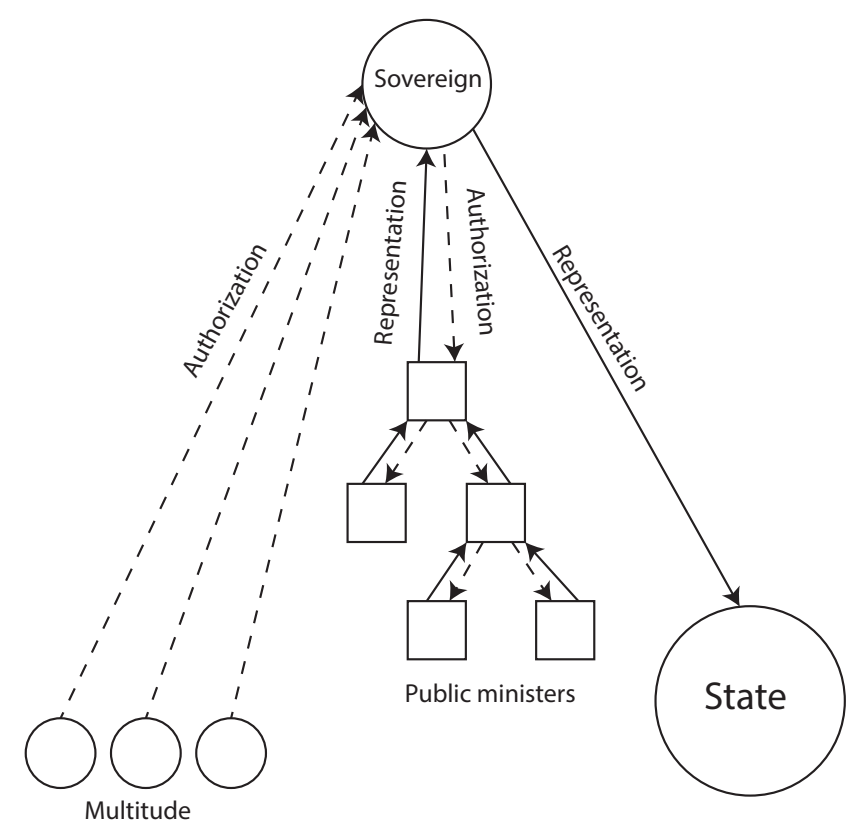

The subjects authorize the sovereign; the sovereign authorizes public ministers; public ministers represent the sovereign; and the sovereign represents the state. The state does nothing; it is only passively represented, like a 'Foole' or a bridge. As Skinner (1999: 22) and Abizadeh (2012: 133-34) argue, Hobbes' state is most similar to 'An Idol, or meer Figment of the brain', such as the 'Gods of the Heathen' (2012: XVI. 248). Although 'Idols cannot be Authors: for an Idol is nothing', the Roman Gods 'were Personated, and held Possessions, and other Goods, and Rights, which men from time to time dedicated, and consecrated unto them' (Ibid.). 'Fooles' and bridges exist regardless of whether anyone represents them, but the state, like a figment of the imagination, ceases to exist if it ceases to be represented: 'a Common-wealth, without Soveraign Power, is but a word, without substance, and cannot stand' (Ibid. XXXI. 554).

11 This diagram is inspired by Runciman's (2009) diagrams. 
What Hobbes gives us is an account of how the state can be a person-that is, can have actions, rights, and responsibilities attributed to it-even though it is not an actor. Although the state has no more agency than a bridge or an idol does, it can properly be said to make laws, sign treaties, borrow money, and exercise the rights of sovereignty as long as the agent who in fact performs these actions has been duly authorized to act in its name.

The contrast between Hobbes' concept of personhood and Samuel Pufendorf's concept of personhood is illustrative. Pufendorf (1934) thought Hobbes had erred in ascribing personhood to non-rational entities:

On this point Hobbes, Leviathan, chap. xvi, is mistaken in holding that in communities a man may frequently represent the person of an inanimate object, which in itself is not a person, such as a church, a hospital, a bridge, \&c. (BI I.12, $11)^{12}$

Pufendorf argued that ascriptions of personhood 'should presuppose such qualities as are appropriate' (Ibid. I.14, 15)—namely, 'intelligence and will'. For this reason, it was 'sheer madness and silly impudence' for Caligula to make his horse a Roman consul and a householder (Ibid. I.15, 15-16) and for Hobbes to describe inanimate things as persons. Whereas Hobbes thought anything that had an authorized representative could be a person, Pufendorf thought only rational agents could be persons. In List and Pettit's (2011: 170-73) terms, Hobbes' conception of personhood is 'performative', while Pufendorf's is 'intrinsicist'. For Pufendorf, the state is 'a single person with intelligence and will, performing other actions peculiar to itself and separate from those of individuals' (1934: BVII II.13, 983; see also Boucher, 2001: 566-67). For Hobbes, the state is a person simply

12 I cite Pufendorf's De Jure according to the book, chapter, and paragraph numbers, as well as the page number from the 1934 edition of the Oldfather translation. 
because it has an authorized representative who wills and acts in its name. ${ }^{13}$ Hobbesian persons, unlike Pufendorfian persons, need not have any intrinsic capacity for rationality or agency.

\section{State Personhood and Corporate Agency}

Hobbes' theory of the state is frequently misunderstood in contemporary political theory and philosophy, where it is often described as a rudimentary theory of corporate agency. According to List and Pettit (2011: 7), Hobbes' "'authorization theory” of group agency ... distinguished three ways a multitude or collection of individuals might form a group agent, particularly a state or commonwealth'. They argue that Hobbes' state is 'a degenerate group agent' that fails to meet the standard of collective rationality (Ibid. 76). As Pettit (2014: 1648) later writes, 'Hobbes takes the group agent that individuals constitute by recruiting an individual spokesperson to be an agent or person only "by fiction"'. Erskine (2001: 75) similarly portrays Hobbes' state as a crude imitation of a corporate agent: 'For Hobbes, the agency of the state is a useful "fiction". Conversely, my aim is to establish the institution as a moral agent in a way that is not simply metaphorical'. Even Hobbes scholars have interpreted him in this way. Baumgold $(1988: 43,51)$ describes what she calls 'Hobbes' nominalist analysis of corporate agency', which explains how 'the multitude forms itself into a "people", or corporate agent'. Garsten (2010: 525) likewise reads 'person' as 'agent': 'to speak of a "people" as if it could want anything, or do anything, was to speak of it as an agent—or, in Hobbes's vocabulary, a "person"—an entity capable of being responsible for words and actions' (Garsten, 2010: 525).

${ }^{13}$ See Holland (2017: Introduction) for a thorough analysis of the differences between Hobbes' theory of the state and Pufendorf's. 
Although 'agent' and 'agency' were not part of Hobbes' political vocabulary, he did seem to suggest that the state is an 'actor', which is roughly the same as an agent. If the state is a person, and 'a Person, is the same that an Actor is' (Hobbes, 2012: XVI. 248), then it follows that the state is an actor. Hobbes' 'Artificiall Man' metaphor also seems to imply that the state is a colossal actor. In addition, he repeatedly says that the state has 'one will' and that actions can therefore be attributed to it (1998: V.9; 2012: XVII. 260). If 'none can make Lawes but the Common-wealth' (2012: XXVI. 416), then it seems that the commonwealth is an agent of some kind.

Although Hobbes' state could indeed be said to will and act, it is not an agent in the sense that contemporary philosophers, political theorists, and IR scholars use the term. Agents, in this sense, are 'intentional—purposive or goal-directed-systems' (Wendt, 2004: 295). In List and Pettit's (2011: 20) terms, an agent is an entity that 'has representational states, motivational states, and a capacity to process them and to act on their basis' — that is, an entity that acts according to its own will and its own conception of its environment. Hobbes' state is not an agent, or even a fictitious agent, by these definitions. As I have previously argued, the state is not a fictional actor or agent, but a fictional character; the sovereign is the (true or fictional) actor or agent who wills and acts in its name. Further, as I argue below, Hobbes' state lacks the defining feature of a corporate agency: a will that is distinct from the wills of its members and representatives.

Recent work in judgment aggregation theory explains how corporate wills can emerge from but nevertheless be distinct from the wills of individuals. For example, Tollefsen (2015: 60-62) describes a scenario in which a three-member admissions committee evaluates $\mathrm{PhD}$ applicants using four criteria: test scores, grades, letters of 
recommendation, and writing samples. Only applicants who meet every criterion will be admitted, and whether a given applicant meets a given criterion will be determined by a majority vote. The committee votes as follows on Mary's application.

Table 2. Tollefsen's admissions committee

\begin{tabular}{|l|c|c|c|c|c|}
\hline & $\begin{array}{c}\text { Good test } \\
\text { score? }\end{array}$ & $\begin{array}{c}\text { Good } \\
\text { grades? }\end{array}$ & $\begin{array}{c}\text { Good } \\
\text { letters? }\end{array}$ & $\begin{array}{c}\text { Good writing } \\
\text { sample? }\end{array}$ & $\begin{array}{c}\text { Accept the } \\
\text { candidate? }\end{array}$ \\
\hline Member \#1 & Yes & No & Yes & No & No \\
\hline Member \#2 & No & Yes & Yes & Yes & No \\
\hline Member \#3 & Yes & Yes & No & Yes & No \\
\hline Committee & Yes & Yes & Yes & Yes & Yes \\
\hline
\end{tabular}

Although none of the individual members of the committee believe that Mary meets all of the criteria for admission, the majority of them believe that she meets each criterion. As a result, the committee decides to admit her to the $\mathrm{PhD}$ program even though none of its members believe that she is a suitable candidate. 'The committee intends to admit Mary' is true even though 'I intend to admit Mary' is false for each committee member. The decision-making procedure of the committee thus produces a corporate will that cannot be ascribed to any particular individual. Even if some members of the committee did share the intention to admit Mary, the committee's will would still be more than an aggregate of individual wills. Corporate intentions are 'multiply realizable', which means that the same corporate intention can be brought about by different combinations of individual intentions (List and Pettit, 2011: 65-66; Tollefsen, 2015: 87-88). The committee might still have decided to admit Mary if each of its members had voted differently, and even if the committee had entirely different members. Having a distinct will, then, is what makes a group a distinct agent. 
Hobbes repeatedly denies that the state has a distinct will. Although he occasionally refers to 'the Will of the Common-wealth', he insists that it is nothing more than 'the Will of the Representative' (Hobbes, 2012: XXVI. 420). Just as the will of a bridge is nothing but the will of its caretaker, the will of a state is nothing but the will of its sovereign: 'a Commonwealth hath no Will, nor makes no Lawes, but those that are made by the Will of him, or them that have the Soveraign Power' (Ibid. XXXI. 570). Similarly, in De Cive, Hobbes says that 'a commonwealth has a will, and can assent and refuse through the holder of sovereign power, and only so' (Hobbes, 1998: VI.19, see also VI.1a). This claim plays a crucial role for Hobbes. If the state had a will of its own, then two seditious possibilities would arise: the state could act independently of the sovereign, or the subjects could object that the sovereign has misrepresented the will of the state. The idea that the state is an agent-that it has a will that is distinct from the will of its representative-is precisely what Hobbes wanted to rule out.

\section{Assemblies as Corporate Agents}

However, Hobbes does allow that assemblies have wills of their own. The will of an assembly, as Hobbes (1998: V.7) says, must be 'understood as the will of the greater part of the men who make up the assembly'. It cannot be identified with the will of any particular individual. A crucial part of Hobbes' theory of the state is that a sovereign representative, which necessarily has a will of some kind, can be an assembly. Whereas states and other 'characters' cannot be said to act unless they are represented by third parties, an assembly can be its own representative, just as an individual can: 'a Monarch, hath the person not onely of the Common-wealth, but also of a man; and a Soveraign Assembly hath the Person 
not onely of the Common-wealth, but also of the Assembly' (2012: XXIII. 376). If there are any rudimentary corporate agents in Hobbes' political thought, they are assemblies, not states. $^{14}$

Yet a Hobbesian assembly differs in some important respects from a corporate agent. While a corporate agent can have intentions that none of its members share, a Hobbesian assembly cannot. If an assembly uses majority rule to decide every issue, as Hobbes suggests, then it cannot have an intention unless the majority of its members also have that intention. Consider the example of the admissions committee once again (Table 2). It is possible for Tollefsen's committee to intend to admit Mary against the wills of each of its members only because the decision-making procedure of the committee is not strictly majoritarian. The members of the committee vote on four 'premises' - whether Mary has a good test score, good grades, good letters, and a good writing sample-and then let their votes on these premises dictate the committee's decision about whether Mary will be admitted. Conversely, a Hobbesian version of this committee would vote directly on whether to admit Mary. Their judgments about whether she satisfies each criterion for admission would not be aggregated. Since all of the members of the committee voted against admitting Mary, the committee would decline to admit her. The will of a Hobbesian assembly, unlike the will of a corporate agent, can never be anything more than the will of the majority.

14 Corporations are not corporate agents either: like states, they will and act only through their representatives. Hobbes repeatedly suggests that states and corporations are persons of the same kind, such as when he describes the latter as 'many lesser Common-wealths in the bowels of a greater' (2012: XXIX. 516; see also 1994: XXVII.7; 1998: V.10). But if sovereign assemblies are similar to corporate agents, as I suggest below, then so are the assemblies of subordinate corporations. 
Pettit (2008: 82-83) argues that Hobbes fails to appreciate the limitations of majoritarian decision-making (see also List and Pettit 2011: 43-46). If the members of an assembly decide every issue using majority voting, then they will likely end up making an inconsistent set of decisions. Pettit uses the example of a three-member assembly that must decide four issues: whether to balance the budget, whether to increase taxes, whether to increase military spending, and whether to increase other spending. Its members vote as follows.

Table 3. Pettit's Sovereign Assembly

\begin{tabular}{|c|c|c|c|c|}
\hline & $\begin{array}{c}\text { Balance the } \\
\text { budget? }\end{array}$ & Increase taxes? & $\begin{array}{c}\text { Increase military } \\
\text { spending? }\end{array}$ & $\begin{array}{c}\text { Increase other } \\
\text { spending? }\end{array}$ \\
\hline Member \#1 & Yes & No & Yes & No (reduce) \\
\hline Member \#2 & Yes & No & No (reduce) & Yes \\
\hline Member \#3 & Yes & Yes & Yes & Yes \\
\hline Assembly & Yes & No & Yes & Yes \\
\hline
\end{tabular}

Although each member of the assembly makes a consistent proposal, the decision of the majority is inconsistent. It is impossible to simultaneously balance the budget, increase military spending, and increase other spending without increasing taxes. This example illustrates a more general problem with majoritarian decision-making. Any assembly that tries to follow the will of the majority on every issue, as Hobbes proposes, will face a “discursive dilemma": they can be responsive to individuals, in which case they will risk collectively irrationality; or they can ensure collective rationality, in which case they may fail to be responsive to individuals' (Pettit, 2008: 83). Pettit argues that assemblies have little choice but to take the second horn of the dilemma. They must side with the minority on some issues-for instance, by increasing taxes against the will of the majority-in order to ensure that their decisions are consistent and actionable. 
Hobbes had obviously never heard of the discursive dilemma, but he would not have been troubled by it. He would simply have grasped the other horn of the dilemma. List and Pettit (2011: 56-58) solve the dilemma through a 'sequential priority procedure', which means letting the assembly's decisions on temporally or logically prior issues determine its decisions on later or derivative issues. In the example above, the assembly might let its decisions on the other three issues dictate its decision about whether to raise taxes. Hobbes would solve the dilemma in precisely the opposite way: by letting later votes overturn earlier votes. As Hobbes (2012: XIX. 290) says, 'the diligent appearance of a few of the contrary opinion, undoes to day, all that was concluded yesterday'. If the assembly first voted to balance the budget, then to increase military spending, then to increase other spending, and then to keep taxes the same, the vote to keep taxes the same would overturn one of the three earlier decisions. The assembly would have to vote again to decide which to overturn.

The underlying principle is that 'The Soveraign of a Common-wealth, be it an Assembly, or one Man, is not Subject to the Civill Lawes. For having power to make, and repeale Lawes, he may when he pleaseth, free himself from that subjection' (Ibid. XXVI. 416). ${ }^{15}$ Anything that the majority decides to do can be undone by a subsequent majority. This Hobbesian solution to the discursive dilemma follows from his theory of sovereignty. States are 'Absolute, and Independent, subject to none but their own Representative' (Ibid. XXII. 348), which means that this representative cannot be bound-not by its subjects, nor

\footnotetext{
${ }^{15}$ Hobbes is deeply hostile to the idea that sovereigns, or even subordinate judges, can be bound by the decisions of their predecessors. As he later adds, 'mens Judgements have been perverted, by trusting to Precedents ... though the Sentence of the Judge, be a Law to the party pleading, yet it is no Law to any Judge, that shall succeed him in that Office' (Hobbes, 2012: XXVI. 434).
} 
by other sovereigns, nor by the decisions of its predecessors, nor even by its previous decisions. Hobbes might have to admit that this solution to the discursive dilemma will not work for subordinate assemblies, such as the boards of companies and universities, which are bound by their prior actions and agreements. In any case, the discursive dilemma presents no problem for Hobbes' theory of the state.

\section{Conclusion}

The main problem with describing Hobbes' state as a corporate agent is not that it is anachronistic, but that it is misleading. Hobbes' state does not have a will, as 'agency' implies; it wills and acts only through its sovereign. If there are any primitive corporate agents in Hobbes' political thought, they are assemblies, not states. It is difficult to fault readers for taking Hobbes at his word in Chapter 16 of Leviathan when he says that persons are actors. Yet focusing too narrowly on this passage, and subsequently ignoring his definition of 'person' from Chapter 42, leads them to project the idea of corporate agency onto Hobbes' state.

What makes his idea of state personhood novel and valuable is precisely that it decouples personhood from agency. Hobbes' 'performative' conception of personhood allows us to sidestep the protracted debates about the metaphysics of corporate agency and intentionality. If we follow Hobbes, then whether corporate entities (and also other artificial entities, such as robots) should have rights and responsibilities need not depend on whether they are really agents. Hobbesian personhood is created out of the political processes of authorization and representation, not discovered through metaphysical speculation. After all, even 'An Idol, or meer Figment of the brain, may be Personated' 
(Hobbes, 2012: XVI. 248). All that an entity requires in order to be a Hobbesian person is an authorized representative who acts in its name.

Many political theorists and philosophers will balk at the suggestion that Hobbes provides a genuine alternative to thinking of the state as a corporate agent, in large part because they are allergic to fictions. They recoil at the idea that the personhood of the state is nothing more than a 'Figment of the brain'. We cling to corporate agency because it gives us something deep and metaphysical on which to hang corporate personhood. Yet more than 240 years since Jeremy Bentham (1891: 155) declared that 'the season of Fiction is now over', fictions remain central to social and political life. Although all of us know better, we speak as though 'the Crown' owns public property in the United Kingdom, and we use bank notes that pretend to be redeemable for gold (Runciman, 2000a: 96; Runciman, 2003: 31). The personhood of the state is one fiction among many. 


\section{References}

Abizadeh, Arash. 2012. "The Representation of Hobbesian Sovereignty." Hobbes Today: Insights for the 21st Century, ed. S. A. Lloyd. Cambridge: Cambridge University Press, 113-52.

Abizadeh, Arash. Forthcoming. "Hobbes's Conventionalist Theology, the Trinity, and God as an Artificial Person by Fiction." The Historical Journal.

Baumgold, Deborah. 1988. Hobbes's Political Theory. Cambridge: Cambridge University Press.

Bentham, Jeremy. 1891. A Fragment on Government, ed. F. C. Montague. Oxford: Clarendon Press.

Boucher, David. 2001. "Resurrecting Pufendorf and Capturing the Westphalian Moment." Review of International Studies 27 (4): 557-77.

Brito Vieira, Mónica. 2009. The Elements of Representation in Hobbes: Aesthetics, Theatre, Law, and Theology in the Construction of Hobbes' Theory of the State. Leiden: Brill.

Copp, David. 1980. "Hobbes on Artificial Persons and Collective Actions." The Philosophical Review 89 (4): 579-606.

Douglass, Robin. 2014. “The Body Politic 'is a fictitious body': Hobbes on Imagination and Fiction." Hobbes Studies 27 (2): 126-47.

Douglass, Robin. Forthcoming. "Authorisation and Representation before Leviathan." Hobbes Studies.

Forsyth, Murray. 1981. "Thomas Hobbes and the Constituent Power of the People." Political Studies 29 (2): 191-203.

Erskine, Toni. 2001. "Assigning Responsibilities to Institutional Moral Agents: The Case of States and Quasi-States." Ethics \& International Affairs 15 (2): 67-85.

Garsten, Bryan. 2010. "Religion and Representation in Hobbes." In Leviathan, ed. Ian Shapiro. New Haven: Yale University Press.

Gauthier, David. 1969. The Logic of Leviathan: The Moral and Political Theory of Thomas Hobbes. New York: Oxford University Press.

Green, Michael J. 2015. "Authorization and Political Authority in Hobbes." Journal of the History of Philosophy 53 (1): 25-47 
Hobbes, Thomas. (1640) 1994. The Elements of Law, Natural and Politic. Oxford: Oxford University Press.

Hobbes, Thomas. (1642) De Cive, trans. Richard Tuck and Michael Silverthorne. New York: Cambridge University Press.

Hobbes, Thomas. (1651) 2012. Leviathan, ed. Noel Malcolm. Oxford: Oxford University Press.

Hobbes, Thomas. (1658) 1991. De Homine. In Bernard Gert, ed., Man and Citizen Indianapolis: Hackett.

Hobbes, Thomas. (1682) 2011. "An Answer to a Book Published by Dr. Bramhall, late Bishop of Derry; called 'The Catching of Leviathan.'” In Leviathan Parts I and II, Revised Edition, eds. A. P. Martinich and Brian Battiste. Peterborough, ON: Broadview, 386-403.

Holland, Ben. 2017. The Moral Person of the State: Pufendorf, Sovereignty and Composite Polities. Cambridge: Cambridge University Press.

Hood, Francis C. 1964. The Divine Politics of Thomas Hobbes: An Interpretation of Leviathan. Oxford: Clarendon Press.

Lessay, Franck. 2009. "Hobbes's Covenant Theology and its Political Implications." In Patricia Springborg, ed., The Cambridge Companion to Hobbes's Leviathan. Cambridge: Cambridge University Press, 243-70.

List, Christian, and Philip Pettit. 2011. Group Agency: The Possibility, Design, and Status of Corporate Agents. New York: Oxford University Press.

Malcolm, Noel. 2012. “General Introduction." In Noel Malcolm, ed., Leviathan. Oxford: Oxford University Press, 1-196.

Martinich, A. P. 2005. Hobbes. New York: Routledge.

Martinich, A. P. 2016. "Authorization and Representation in Hobbes's Leviathan." In A. P. Martinich and Kinch Hoekstra, eds., The Oxford Handbook of Hobbes. Oxford: Oxford University Press, 315-38.

Pettit, Philip. 2008. Made with Words: Hobbes on Language, Mind, and Politics. Princeton: Princeton University Press.

Philip, Pettit. 2014. "Group Agents Are Not Expressive, Pragmatic or Theoretical Fictions." Erkenntnis 79 (s9): 1641-62. 
Pitkin, Hanna F. 1967. The Concept of Representation. Los Angeles: University of California Press.

Pufendorf, Samuel. 1934 [1672]. De jure naturae et gentium libri octo, trans. W. A. Oldfather. Oxford: Clarendon Press.

Runciman, David. 2000a. “Is the State a Corporation?” Government and Opposition 35 (1): 90-104.

Runciman, David. 2000b. "What Kind of Person is Hobbes's State? A Reply to Skinner." The Journal of Political Philosophy 8 (2): 268-78.

Runciman, David. 2003. "The Concept of the State: The Sovereignty of a Fiction." In Quentin Skinner and Bo Stråth, eds., States and Citizens: History, Theory, Prospects. Cambridge: Cambridge University Press, 28-38.

Runciman, David. 2009. “Hobbes's Theory of Representation: Anti-Democratic or ProtoDemocratic?" In Ian Shapiro et al., eds., Political Representation. Cambridge: Cambridge University Press, 15-34.

Runciman, David. 2016. "The Sovereign." In A. P. Martinich and Kinch Hoekstra, eds., The Oxford Handbook of Hobbes. Oxford: Oxford University Press, 359-76.

Simendic, Marko. 2012. "Thomas Hobbes's Person as Persona and 'Intelligent Substance." Intellectual History Review 22 (2): 147-62.

Skinner, Quentin. 1998. Liberty Before Liberalism. Cambridge: Cambridge University Press.

Skinner, Quentin. 1999. "Hobbes and the Purely Artificial Person of the State." The Journal of Political Philosophy 7 (1): 1-29.

Skinner, Quentin. 2005. “Hobbes on Representation." European Journal of Philosophy 13 (2): 155-84.

Skinner, Quentin. 2009. "A Genealogy of the Modern State." Proceedings of the British Academy 162: 325-70.

Tollefsen, Deborah. 2015. Groups as Agents. Malden, MA: Polity.

Tuck, Richard. 2016. The Sleeping Sovereign: The Invention of Modern Democracy. Cambridge: Cambridge University Press.

Tukiainen, Arto. 1994. "The Commonwealth as a Person in Hobbes's Leviathan." Hobbes Studies 7 (1): 45-55. 
Turner, Henry S. 2016. The Corporate Commonwealth: Pluralism and Political Fictions in England, 1516-1651. Chicago: University of Chicago Press.

Wright, George. 2006. Religion, Politics and Thomas Hobbes. Dordrecht: Springer.

Sean Fleming. 2017. "The Two Faces of Personhood: Hobbes, Corporate Agency, and the Personality of the State." Forthcoming in the European Journal of Political Theory. 